\title{
Customer satisfaction in tourist destination: The case of tourism offer in the city of Naples
}

\author{
Valentina Della Corte*, Mauro Sciarelli, Clelia Cascella, Giovanna Del Gaudio \\ Department of Economics, Management, Institutions, University of Naples Federico II, Naples, Italy \\ Email address: \\ valentina.dellacorte@unina.it (V. D. Corte), mauro.sciarelli@unina.it (M. Sciarelli), clelia.cascella@unina.it (C. Cascella), \\ giovanna.delgaudio@unina.it (G. D. Gaudio)
}

\section{To cite this article:}

Valentina Della Corte, Mauro Sciarelli, Clelia Cascella, Giovanna Del Gaudio. Customer Satisfaction in Tourist Destination: The Case of Tourism Offer in the City of Naples. Journal of Investment and Management. Special Issue: Attractiveness and Governance of Tourist Destinations. Vol. 4, No. 1-1, 2015, pp. 39-50. doi: 10.11648/j.jim.s.2015040101.16

\begin{abstract}
This paper investigates the main elements that can influence customer satisfaction in tourist services, with specific reference to tourism industry. The importance of this topic resides in the fact that tourists' positive experiences of service, products, and other resources provided by tourism destinations can produce customer retention as well as positive word-of-mouth. Indeed, satisfaction with travel experiences contributes to destination loyalty. The degree of tourists' loyalty to a destination is reflected in their intentions to revisit the destination and in their recommendations to others. Thus, information about tourists' loyalty is important to destination marketers and managers in order to sustain destination attractiveness. Although predominant literature has adopted a demand-side perspective, this paper analyses tourist satisfaction according to an overlapping perspective that contemplates both the demand and the offer side where this latter, in the wider meaning, also includes the systemic perspective. More precisely, this paper aims to identify the principle competitive strategies that the variety of stakeholders, cooperating together in a destination, has to implement in order to increase tourist satisfaction and loyalty. Indeed, the point of view of this paper is to understand how destination attributes and services affect the tourist satisfaction. In order to study the link between destination attributes and tourist satisfaction, the paper collects cross-sectional data via questionnaire, from May 2012 to May 2013. The adopted approach allows to individuate the factors that can influence tourist satisfaction, their (positive or negative) direction and their magnitude. This paper uses 14 tourist satisfaction indicators in order to measure the global satisfaction. Furthermore, this study allows to identify the current strengths and weaknesses of the tourist offer. In particular, the study paid attention to the phase of service delivery since it is the time when customer satisfaction is generated. From this study, it comes out that tourist satisfaction depends on a complex process where the role of each actor is fundamental and it must be in tune with all the other ones. Findings show that tourists visiting Naples are not completely satisfied, supporting that Naples has not a clear destination image.
\end{abstract}

Keywords: Tourist Satisfaction, Destination Attractiveness, Destination Image, Destination Attributes, Tourist Experience

\section{Introduction}

Customer satisfaction has always been considered an essential objective in all market sectors, because it is assumed that satisfied customers would repurchase the product/service and are more likely to develop product loyalty.

The aim of this paper is to trace an advancement on the topic of customer satisfaction understanding which can effectively be its determinants. This represents the starting point of the research agenda. Indeed, the paper begins by defining the concept of customer satisfaction to after find, through a literature review, the elements generating customer satisfaction. The paper follows a precise choice about the application of the concept of customer satisfaction in the tourist destinations as, this unit of analysis, allows to understand the real complexity of the topic. Indeed, the empirical application helps to precisely comprehend the link between determinants of satisfaction. The paper concludes with a discussion of the main findings.

Customer satisfaction is determined by "overall feelings, or attitudes, a person has about a product after it has been purchased" (Solomon, 2002): it is often found to be at the heart of firms' marketing activities (Machleit and Mantel, 2001), because it helps them achieving their desired strategic objectives. A higher level of consumer satisfaction can 
increase customer loyalty (Fint et al., 2011; Qi et al., 2012), reduce price elasticity (Fornell et al., 2006), lower transaction costs (Yang and Peterson, 2004), improve the capacity of attracting new customers (Uncles et al., 2013), help developing a strong reputation in the marketplace (Walsh et al., 2009; Rust et al., 1995) and have a direct impact on the customer retention (Rust et al, 1995). Thus, customer satisfaction is considered as an essential indicator of a company's overall performance.

The core concepts within the research stream of customer satisfaction are assumed by the "service quality" (Lazarus, 1991; Kuo et al., 2009; Zhao et al., 2012) and the "value of the product/service", which in turn depends on the price paid for it (De Rust and Oliver, 1994; Nilsson et al., 2001; Morgeson et al., 2011). The higher is the quality in relation to the price paid, the greater is the value perceived by consumers (Ostrowski, O'Brien and Gordon, 1993; Stock, 2011: Blocker and Flint, 2011).

Furthermore, it is important to underline that customer satisfaction is a post consumption evaluation that disappoints, meets or exceeds expectations and is based on the overall experience (Wang and Yang, 2004).

Expectations are defined as "the individual's beliefs about how a product is likely to perform in the future" (Oliver, 1987). The direct effect of expectations can be explained by the Assimilation Theory (Sherif and Hovland 1961): individuals suffer a psychological conflict when they perceive discrepancies between performance and prior beliefs. Subsequently, consumers tend to adjust perception to their expectations in order to minimize or remove that tension (Oliver 1997). Thus, the assimilation effect can be described as a tendency to process new consumption experiences in terms of existing beliefs. Under these circumstances, satisfaction will be led by expectations (Cherry et al., 2003; Frank and Encawa, 2009; Blocker and Flint, 2011). In this perspective, customer satisfaction is defined by customer's post-purchase assessment of service delivered and comparison of customer's expectations and the actual service experience (Spreng and Dröge, 2001; Higgs et al., 2005; Del Bosque et al., 2006). It is important to underline that in the social network era (Brown et al., 2007; Hartley, 2008), this ex post stage can also take place in real time. Indeed, social networks allow the customers to post comments about the experienced service/product both in a post consumption phase and in real time. The satisfaction, being an attitudinal measure (Grisseman and Stockburger-Sauer, 2012) and not a temporal one, has not a precise moment in which it can be expressed by the customer. However, these new tools make the process extremely fast, becoming by far more influential for firms' management.

Customer satisfaction is often defined in the marketing literature as a customer's overall evaluation of his or her purchase and consumption experience of a good or service (Hui et al., 2007; Flint et al., 2011; Qi et al., 2012); it is critically important because it reflects subjective customer evaluations, an emotional response associated with the consumption experience (Kumar, 2005; Grewal et al., 2009;
Falk et al, 2010). Similarly, Oliver (1989) established that emotions deriving from evaluations will determine the individual's overall response in the consumption process. This cognitive-affective approach is of great value for application in this study since emotional responses are essential components of the destination experiences (Bigné et al 2005; Ryan 1995).

The importance of emotions in the consumer behavior models has increased significantly during the last few years (Loken, 2006). In particular, it should be emphasized that the cognitive system and emotional states play an important role in satisfaction formation. The higher mental processes of understanding and evaluation would be performed by the cognitive system, whereas emotions would be related to the individual's feelings towards the service (Van Dolen et al, 2004). Finally, loyalty or commitment with respect to a brand is conceived as the main consequence of satisfaction (Brady and Robertson, 2001; Selnes 1993; Yu and Dean, 2001).

Based on this discussion, it is clear that customer satisfaction depends on the existence of overlapping elements such as the indicators and the ex-ante expectations. This expresses the multifaceted nature of the topic of customer satisfaction.

In recent years, the role of the consumer has changed from a passive purchaser to an active protagonist of the products/service creation (Arussy, 2002; Hetzel, 2002; LaSalle, Britton, 2003; Shaw, Ivans, 2004; Yastrow, 2003). The centrality of the "experience" concept has been reinforced by the technological innovations in the fields of goods purchase and consumption. The consumer wants to be more involved and be on of the main actors in product/service creation.

Concerning this perspective, the experiential approach focuses on the affective and emotional component of the consumption process. The concept of "experience" is strictly connected with the entertainment aspect and implies the consumer participation and interaction during the product/service creation. Building an experience means bring the product/service to life and underline its identity through the sensorial involvement of the consumer (Shaw, Ivens, 2002; Smith, Wheeler, 2002). Pine and Gilmore (2011) define the experience as the main subject of exchange with the consumer: it can be considered as a new type of supply, along with tangible products and intangible services.

The existing literature demonstrates that customer satisfaction can depend on a series of elements that belong to the subjective sphere of the customer and to the objective quality of the product/service experienced. Some works concentrate their attention on the individual components influencing the satisfaction (customer perspective), while others focus on the intrinsic features of the product/service and on the way through which it is delivered (firm perspective). Hence, customer satisfaction is the result of an overlapping perspective. Actually, it is possible to add another perspective to the already existing two. This is the systemic perspective that is verified when it is dealt with complex products such as the tourist product one. Therefore, this paper 
also adopts the systemic perspective, proposing a design of the paper that adheres to this scheme both in literature background and in the empirical session.

More precisely the objective of the paper is to:

- understand the relationship between the antecedents of customer satisfaction adopting an offer-side perspective;

- comprehend if it exists a systemic perspective in the topic of customer satisfaction of complex product/service and what are the elements that contribute to shape it;

- identify the perception of the customer about the main components of satisfaction, considering so the demand-side perspective

\section{Customer Satisfaction in Tourism Industry}

In the tourism context the concept of tourist satisfaction is particularly relevant as well as difficult to deal with as the tourist product is "complex" by definition (Smith, 1994). Furthermore, due to the global competition destinations and, more precisely, DMOs (Destination Management Organizations) are facing the competition at global level.

In this scenario destination competitiveness acquires a strategic role (Kozak and Rimmington, 1999) in order to determine the actual and future success of destination itself.

According to some authors (Kozak and Rimmington, 1999) some attributes can contribute to the real destination competitiveness. These attributes refer to the variables that influence the satisfaction or dissatisfaction of tourists during their vacation.

This is the reason why this paper analyzes the issue of tourist satisfaction.

Indeed, it can be easily noticed that the contemporary tourist wants to live a unique experience and is not interested anymore in purchasing a standardized product/service: in order to meet the new needs of the demand, the tourist destinations must give top priority to the achievement of tourist satisfaction.

The literature concerning this subject is limited due to the several aspects defining this issue and the consequent lack of a holistic perspective. This holistic vision should include the cognitive, affective and systemic (Hartman, 1973) constructs of tourist satisfaction and the attributes that characterize the destination.

In other words, tourist satisfaction has to be analyzed according to an overlapping perspective that contemplates both the demand and the offer side where this latter, in the wider meaning, also includes the systemic perspective.

Although predominant literature has adopted a demand-side perspective (Fields 2002; Xia et al., 2009), this paper aims to identify the principle competitive strategies a tourist destination has to implement in order to increase tourist satisfaction and loyalty. Indeed, the point of view of this paper is to understand how destination attributes and services affect the tourist satisfaction.
The previously cited literature illustrates the importance of customer satisfaction and loyalty for the product/service, which is also linked to firm's performance metrics such as higher profitability and repurchase (Kumar and Petersen, 2005; Fornell et al., 2006). Satisfaction reflects "a positive affective state resulting from a customer's cumulative appraisal of its provider relationship" (Lam et al., 2004); customer satisfaction is crucial in all market sectors due to its great impact on future consumer intentions, loyalty and word-of-mouth communications. Its centrality increases in those fields in which the product/service to be delivered is mainly intangible and the principle challenge is the confection of an experience that perfectly matches the consumer's expectations. That is why this paper focuses on customer satisfaction in the tourism market.

The importance of the topic of tourist satisfaction is testified by many academic contributions, whose literary production started in the 1960s (Xia et al., 2009), and by the increasing attention that practitioners have given to this research issue.

Of course numerous scholars have questioned on what tourist satisfaction depends and, hence, have challenged themselves to the research of those elements that could influence the generation of tourist satisfaction.

Within these studies, there is a research stream supporting the vision that the destination image affects the tourist satisfaction (Cooper, Fletcher and Gilbert, 1993; Lee et al, 2002).

Actually, one of the main gaps is that most of works that analyse this bond between destination image and tourist satisfaction do not linger on behavioral consequences of tourists "such as loyalty and positive word-of-mouth" (Veasna et al., 2013) related to the destination. These latters, in a measure, can be the sources of destination image. Indeed, "destination image is defined as an attitudinal concept consisting of the sum of beliefs, ideas and impressions that a tourist holds of a destination" (Hosany et al., 2006). The destination image plays a key role for the choice of the destination, for the consecutive evaluation and for the future intentions to return and recommend it (Bigné et al., 2001; Chen and Tsai, 2007).

The explosion of contributions that conceive destination image as an antecedent of tourist satisfaction represents a clear gap in literature.

This vision, indeed, appears fairly reductive and static since it does not consider that destination image can be influenced by the experience itself (Oliver and Burke, 1999; Rodríguez del Bosque and San Martín, 2008). The modification of destination image, hence, can also be conceived as consequence of satisfaction.

In the light of these observations, this paper is exactly developed on the existence of a clear relationship between tourist satisfaction and destination image.

To better understand this relationship, the article is outlined to first understand what are the items that influence the tourist satisfaction to after capture the destination image shaped in the mind of the tourists. 
If tourism literature has mostly focused the attention on tourism satisfaction, this is due to the fact that from it a series of concepts descends such as loyalty (Song et al, 2012) or tourist complaints (Lee et al., 2011).

With reference to the tourism sector, a review of the literature on motivation reveals that people travel because they are "pushed" into making travel decisions by internal, psychological forces, and "pulled" by the external forces of the destination attributes (Crompton, 1979; Dann, 1977; Uysal and Jurowski, 1994). Accordingly, satisfaction with travel experiences, based on these push and pull forces, contributes to destination loyalty. The degree of tourists' loyalty to a destination is reflected in their intentions to revisit the destination and in their recommendations to others (Oppermann, 2000). Thus, information about tourists' loyalty is important to destination marketers and managers.

The complexity of the theme of tourist satisfaction depends on its richness in terms of contents. The satisfaction, in general, is a latent variable (Bagozzi et al, 1981; Fornell et al., 1996; Fonseca, 2009; Kaplan et al., 2007; Song et al, 2012) that, in order to be defined needs to consider what are the antecedents determining it as well as the consequences and the relative relationships among the indicators that are the expression of tourist satisfaction.

Literature on this subject measures the tourist satisfaction in different ways. These differences can depend on the use of various methodologies and indicators.

Since satisfaction derives from a post-purchase analysis (Fornell, 1992; Westbrook and Oliver, 1991), studies have indicated innumerable measures to evaluate travel experience (Bramwell, 1998).

This experience implies an encounter with the service and the relative "judgment" (Bowen and Schouten, 2008) expressed by tourists after their experience that can determine satisfaction or dissatisfaction. The theme is dealt with the perspectives of overall satisfaction (Wan and Chan, 2013).
According to a destination management approach (Xia et al., 2009), destination attributes are of fundamental importance for the valuation of the experience (Alegre and Garau, 2010). The evaluation is also the result between the attributes and the ex ante tourist's expectation (Tribe and Snaith, 1998).

Within this theoretical context, several authors (Ekinci and Hosany, 2006; Usakli et al.,2011; Qu et al., 2012) have adopted the concept of destination image: in order to achieve the desired outcomes, the building of a coherent brand image and the way the destination is perceived by actual and potential tourists are considered as the principal factors upon which depends the success of the destination itself (Voase, 2012).

The image could be defined as the "set of values, ideas and impressions a destination is able to stimulate in the minds of the actual and potential tourists" (Della Corte, Micera, 2007). The peculiarity of this vision focuses on the impressions the destination could and must induce both in the potential tourist (induced marketing level), both in the effective visitors (organic marketing level).

During the transmission process of the positive associations, it is important to avoid stereotypes (Kotler et al., 1993) and be able to create and to manage a unique brand image, especially if the destination has a multiple tourist vocation and deals with a variety of different products/services (Della Corte, 2009). The procedure is even more complicated when the destination is characterized by contradictory factors (Ruzzier, de Chernatony, 2013), between which some are able to transmit positive images (such as artistic or natural beauties etc.), some are completely negative (like traffic, criminality, etc.). In addition to this, it is important to underline that the contemporary market is unpredictable and in constant expansion, so it is difficult to build and coordinate an image able to reach the entire target, constituted by both the loyal and the new customers (Ferns and Walls, 2010; Ekinci et al., 2013).

Table 1. Items of tourist satisfaction

\begin{tabular}{lll}
\hline Item & Literature on tourist satisfaction using these items & 6As Model \\
\hline $\begin{array}{l}\text { Easy access through different } \\
\text { modes of transportation }\end{array}$ & Wan and Chan, 2011; 2013; Della Corte, 2013; Kozak and & Access \\
Accommodation & Rimmington 1998; Kozak, 2001; Vetter, 1985 & Accommodation \\
Quality of streets and road-signs & Xia et al, 2009; Hui et al 2007; Ekinci et al., 2003; Kozak, 2001 & Access \\
Restaurants' quality and diversity & Xia et al, 2009; Hui et al 2007; Nield et al., 2000 & Amenities \\
Entertainment & Mikulić and Prebežac, 2011; Xia et al, 2009; Wan and Chan, 2013; & Amenities/Ancillary services \\
Price and value & Coghlan, 2011 & Access, Attractions, Amenities, Ancillary \\
On stage information accessibility & Ortega and Rodríguez, 2007 & services, Assemblage, Accommodation \\
Local transport & Xia et al, 2009; Thompson and Schofield, 2007; Kozak, 2001 & Access \\
Perceived security & Tasci and Boylu, 2010; Weiermair and Fuchs, 1999 & Access, Attractions, Amenities, Ancillary \\
& & services, Assemblage, Accommodation \\
Disabled friendly infrastructures & Daniels et al., 2005 & Access, Attractions, Amenities, Ancillary \\
Cleanliness of the city & Xia et al, 2009; Merrilees et al., 2009; Alegre and Garau, 2010 & - \\
Hospitable (local) people & Jenkins, 1999; Kozak, 2001; Yoon and Uysal, 2005) Accommodation \\
Organization of cultural events & Chhabra et al., 2003; Kim et al., 2010; Kruger et al., 2013 & - \\
Activities & Bowen and Schouten, 2008; Danaher and Arweiler, 1996; Kozak, & Amenities/Ancillary services \\
\hline
\end{tabular}


Working on the brand and the image means dealing with the process of connection between induced and organic level: it is important to keep strong the coherence with the reality of the local supply, in order not to cause a "boomerang effect" and a negative word of mouth (Hudson and Ritchie, 2009). In the destination customer satisfaction pyramid (Della Corte, 2000) it is underlined the centrality of the quality of the tourist products and services truly provided in the destination. The organic level marketing, hence, is an essential component of the customer satisfaction and retention (Della Corte, 2009).

\section{Methodology}

Indeed, scholars use different measures to analyse the effects of attributes on tourist satisfaction. In order to identify the right indicators, this study has proceeded with a systematic review on the works related to tourist satisfaction to understand what items have been taken into account.

Furthermore, this paper conceives these indicators in the light of the scheme of the 6As model (Cooper et al., 1993; Della Corte, 2013), according to which a destination is characterized by the following features: 1 . access; 2 . attractions; 3. accommodation ; 4. amenities; 5. assemblage 6. ancillary services. Indeed, variables are also grouped according to this scheme.

This review has led to the identification of fourteen indicators, that precisely are:

- Easy access through different modes of transportation: several studies (Wan and Chan, 2011; 2013; Della Corte, 2013; Kozak and Rimmington 1998; Kozak, 2001) emphasize the important role of accessibility. The mode of transport used to access the destination contributes in a real way to the overall satisfaction (Vetter, 1985);

- Accommodation: extant literature (Xia et al, 2009; Nash et al., 2006) on tourism satisfaction reveals that accommodations are strategic players for both the competitiveness of the destination (Ekinci et al., 2003) and the tourist satisfaction itself.

- Quality of streets and road-signs: although this is an underestimate attribute within tourism satisfaction literature, during the phase of fruition the creation of a supportive environment rather than complicated can surely avoid dissatisfaction and complaints. Despite previous literature on the topic, we decide to include this variable in the current study since its can produce dissatisfaction.

- Restaurants' quality and diversity: according to some authors (Nield et al., 2000; Kim et al., 2010) the issue of "food service experience" has been understimated within the works studying tourist satisfaction. Since that the consumption of food and beverage in a destination depends on physical, cultural, interpersonal, and status motivations (Fields, 2002), this indicator becomes of extreme importance for the evaluation of satisfaction. In particular the attention in previous studies is stressed on variety, quality and price of food (Hui et al 2007).
- Entertainment: some studies find that entertainment has effect on tourist satisfaction (Mikulić and Prebežac, 2011; Xia et al, 2009; Wan and Chan, 2013; Coghlan, 2011). Entertainment per se cannot generate satisfaction but rather its quality, variety and attractiveness (Mikulić and Prebežac, 2011) is able to influence the satisfaction with the destination.

- Price and value: the perception of price and value is examined in previous studies as it is considered "one consistent satisfaction attribute" (Yu and Goulden, 2006, p.1338).

- On stage information accessibility: during the organic phase the access to local tourist information is of fundamental importance. In the digital age, the information can be delivered through the traditional tourist information center or the most advanced mobile devices. Literature on tourist information has overemphasized the importance of tourist information for destination choice and, hence, at the induced level (Jacobsen and Munar, 2012), underestimating the role of access to information at organic level. The search for information and the relative accuracy and promptness contribute to partial satisfaction. As Ortega and Rodríguez (2007, p. 147) underline that "tourism literature needs more research about information at destinations". This is the reason why this paper takes into account this variable.

- Local transport: the availability and perceived quality of local transport at tourist destinations has been established as exercising an influence on visitor experience, overall satisfaction and repeat visitation (Thompson and Schofield, 2007)

- Perceived security: safety and security of a destination are seen to have a big impact on the level of satisfaction with a tourist trip (Tasci and Boylu, 2010).

- Disabled friendly infrastructures: studies reveal that the combination of barriers affecting travellers with disabilities may operate to decrease their travel satisfaction (Daniels et al., 2005).

- Hospitable (local) people: friendliness and hospitality of the locals is one of the principal destination attributes that leads to tourist satisfaction (Jenkins, 1999; Kozak, 2001; Yoon and Uysal, 2005).

- Organization of cultural events: the high perception of authenticity of the destination can be pushed by the organization of cultural events, related to heritage, gastronomy, music etc. Studies demonstrate that the organization of cultural events could be a measure of product quality and a determinant of tourism satisfaction (Chhabra et al., 2003; Kim et al., 2010; Kruger et al., 2013).

- Cleanliness of the city: various scholars demonstrate that cleanliness and hygiene of the city are one of the main determinants of tourist satisfaction with the destination, while dirtiness is a clear factor of dissatisfaction (Merrilees et al., 2009; Alegre and Garau, 2010). 
- Activities: the availability of a variety of activity (Bowen and Schouten, 2008; Danaher and Arweiler, 1996; Kozak, 2001) can assure the tourist satisfaction. The paper considers under the voice "activities" all the other activities not previously estimated in the questionnaire.

As viewed, there are many attributes which affect the tourist satisfaction. The complexity of a destination in terms existing factors makes difficult to evaluate the overall satisfaction. This is the reason why we considered the above-identified concepts as items of partial satisfaction since each of them contributes to define the level of satisfaction globally achieved by the tourist. From here the research question at the basis of the paper is: Do these factors singled out of the literature on the topic effectively influence tourist satisfaction?

\subsection{Data Collection}

The data of this paper was collected in Naples during the period May 2012-May 2013. Naples is a city located in Southern Italy with 2.166 .518 presences and 918.485 visitors arrivals per year (Ente Provinciale del Turismo, 2014).

The survey was conducted through an ad hoc questionnaire, administrated to a convenience sample during three different periods of time in order to better capture the dynamicity of tourist satisfaction.

The questionnaires was pre-tested in May 2012 and later distributed in December-January and again in May 2013.
Respondents were selected by using convenience criteria, that means be based on the tourists' availability to be interviewed.

The questionnaires have been administered in "collecting areas" (Levy and Lemeshow, 2011) that, in our case, are the INFOPOINTs (i.e. tourist information offices activated by the city of Naples) and some hotels. In particular, for each grading class, the number of selected hotels is proportional to the number of hotels that compose the relative grading (population) class.

We collected cross-sectional data, i.e. data gathered by administering the same questionnaire to different samples composed by tourists characterized by similar features. The principal limitation of this study is our sampling design: we used little and convenient samples, constituted by 120 units in the first wave and 200 units in the second wave: for this reason, our findings cannot be generalized to the entire population. Nevertheless, this paper is aimed at developing a practical brief "guide" that can be used to monitor each satisfaction level over time. Therefore, by using our simple empirical approach it is possible to highlight strengths and weaknesses of the current local offer.

The units that compose our samples, in each wave, have similar features (tab. 2) and this factor facilitates the comparison between the results obtained by using our methodology.

Table 2. Descriptive statistics

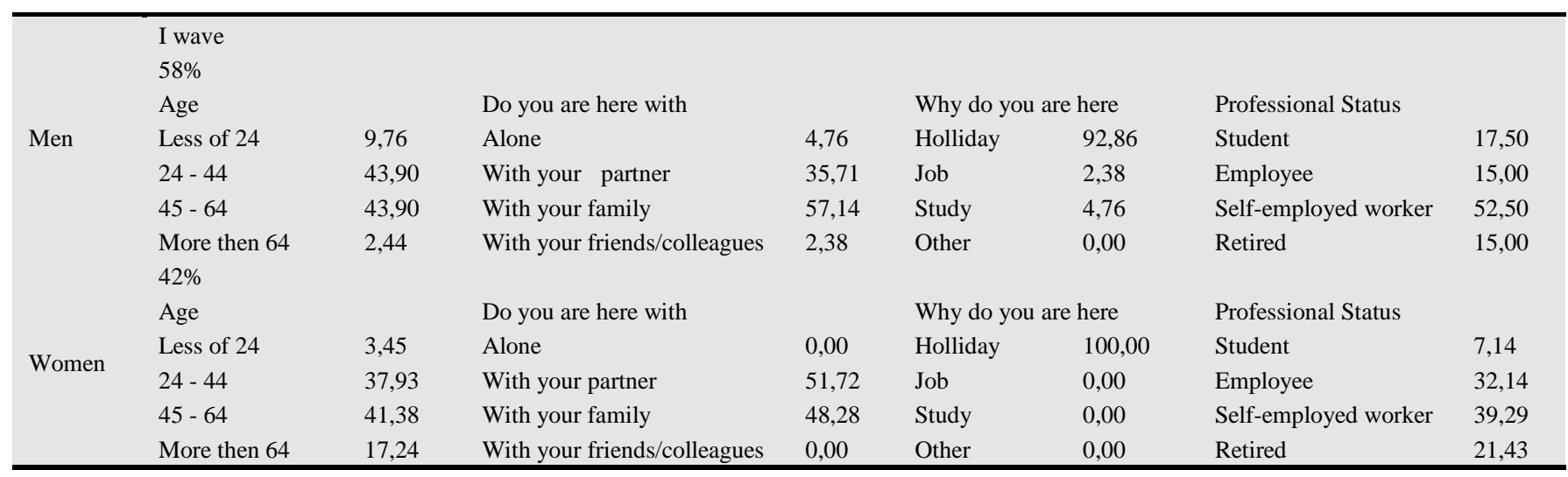

Table 2. Continued

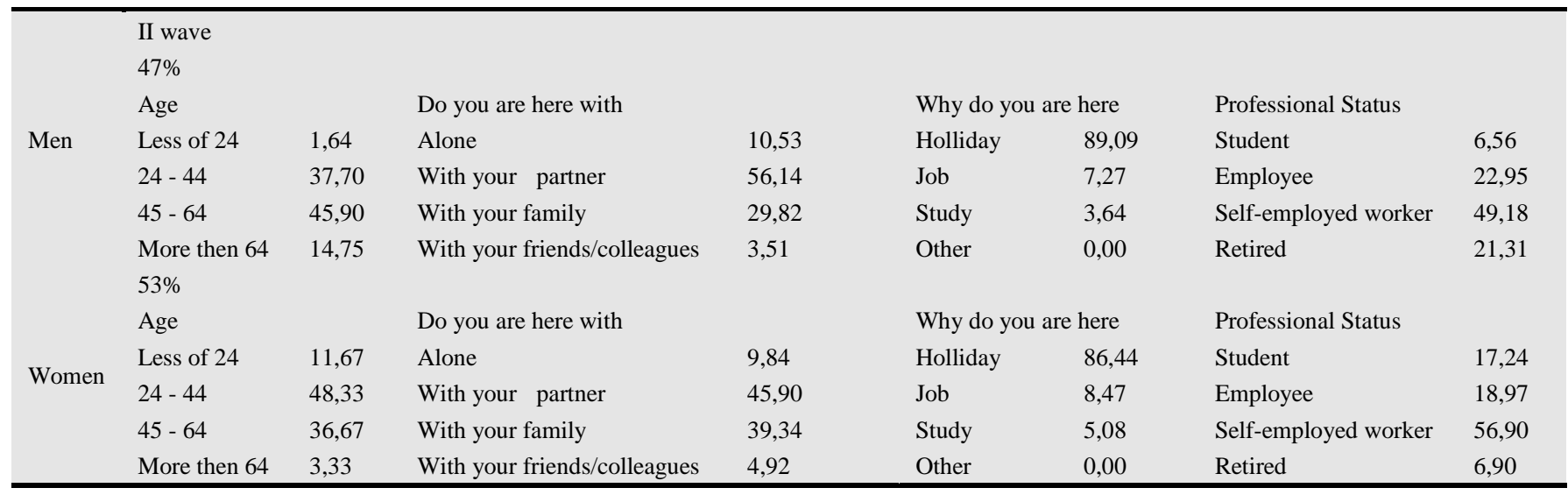




\section{Customers' Satisfaction Analysis}

In order to measure the impact of our 14 partial satisfaction indicators, we calculated the attributable risk, that is a version of the traditional odd-ratio. The attributable risk expresses the proportion of unsatisfied units (of tourists) attributable to one or more risk factors (i.e. in our case it is imputable to the dissatisfaction connected to the partial satisfaction indicator). Therefore, we can pinpoint all the factors that can influence the tourist experience in Naples and we can also quantify the magnitude of such influence. In other words, the attributable risk index defines the proportion of unsatisfied units that can be removed by eliminating the risk factor (Buzzetti and Mastroiacovo, 2000).

Before calculating this index, we analyzed the internal consistency of our set of partial satisfaction indexes by using the Cronbach's alpha. The items' internal consistency is a property of scales and concerns empirical indicators of a general concept (Giampaglia, 1990; Corbetta, 1999). Since these indicators are indirect tools useful to reveal a general concept, they imply both casual and systematic errors. By using the reliability analysis, and in particular by implementing the Cronbach's alpha, we can obtain a measure of reliability level of selected indicators. So, in other words, we can ascertain that selected items constitute a one-dimensional scale, i.e. they are able to reveal the underlying dimension that, in our study, is the global tourist satisfaction (Nunnally, 1978).

When the alpha value is higher than 0.75 , it confirms the internal consistency of the partial satisfaction indicators (table $3)$.

Table 3. Internal consistency (Cronbach $\alpha)$

\begin{tabular}{lll}
\hline & Alpha & N items \\
\hline I wave & 0.864 & 14 \\
II wave & 0.889 & 14 \\
\hline
\end{tabular}

By carrying out a descriptive analysis, we can immediately individuate satisfying, unsatisfying and neutral factors.

Among the satisfying factors, we can pinpoint the comfort and the esay access through different modes of transportation, the accommodation, the restaurants' quality and diversity, the price and value, the perceived security, other (not specified by us) activities that are interesting for the tourists interviewed and hospitable local people. Those factors are mainly delivered by local private actors, with the exception of one variable (perceived security), guaranteed by the city of Naples (table 4).

Table 4. Satisfier factors (I wave)

\begin{tabular}{llllllll}
\hline & $\begin{array}{l}\text { Easy access through } \\
\text { different modes of } \\
\text { transportation }\end{array}$ & Accommodation & $\begin{array}{l}\text { Restaurants' } \\
\text { quality and } \\
\text { diversity }\end{array}$ & $\begin{array}{l}\text { Price } \\
\text { and } \\
\text { value }\end{array}$ & $\begin{array}{l}\text { Perceived } \\
\text { security }\end{array}$ & $\begin{array}{l}\text { Other } \\
\text { activities }\end{array}$ & $\begin{array}{l}\text { Hospitable } \\
\text { (local) } \\
\text { people }\end{array}$ \\
\hline unsatisfied & 12,50 & 7,59 & 7,27 & 3,33 & 16,39 & 26,00 \\
uninteresting & 25,00 & 34,18 & 29,09 & 15,00 & 24,59 & 32,00 & 3,08 \\
satisfied & 62,50 & 58,23 & 63,64 & 81,67 & 59,02 & 42,00 & 90,77 \\
& 100,00 & 100,00 & 100,00 & 100,00 & 100,00 & unsatisfied & satisfied \\
\end{tabular}

Table 5. Neutral and/or satisfier factors (I wave)

\begin{tabular}{llll}
\hline & Entertainment & On stage information accessibility & Cultural events' organization \\
\hline unsatisfied & 24,24 & 26,15 & 26,00 \\
uninteresting & 39,39 & 36,92 & 34,00 \\
satisfied & 36,36 & 36,92 & 40,00 \\
& 100,00 & 100,00 & 100,00 \\
\hline
\end{tabular}

Table 6. Internal consistency (Cronbach $\alpha$ )

\begin{tabular}{lllll}
\hline & Public transportation & Disabled-friendly infrastructures & Quality of streets and road-signs & Cleanliness of the city \\
\hline unsatisfied & 84,06 & 92,00 & 38,33 & 79,37 \\
uninteresting & 13,04 & 2,67 & 45,00 & 11,11 \\
satisfied & 2,90 & 5,33 & 16,67 & 9,52 \\
& 100,00 & 100,00 & 100,00 & 100,00 \\
\hline
\end{tabular}

Other services delivered by the city of Naples (in such cases, in cooperation with local actors) are differently perceived and can be classified as neutral or (quite) satisfying factors (table 5).

Finally, among the dissatisfying factors, we can list the public transportation, disabled-friendly infrastructures, the quality of the streets and road-signs and the cleanliness of the city. All those factors are guaranteed by the city of Naples (table 6).

In order to appreciate the magnitude of each indicator on global satisfaction, we can calculate the attributable risk $(R A)$.

Then, for example, the first index (related to easy access through different modes of transportation) is equal to 0,20 . It means that we could diminish the number of unsatisfied customers $(-20 \%)$ if we improve the comfort and the frequency of access through different modes of transportation. Therefore, the bigger is the value of attributable risk, the greater is the impact of each occurring indicator. So, according to findings showed in table 6 , it is clear that some variables, such as amusement $(0,05)$ and perceived security 
$(0,08)$ are neutral (Cadotte and Turgeon; 1988), i.e. they do not have an appreciable influence on the global customer satisfaction. Viceversa, other factors, such as the hospitality of the locals $(0,40)$ or the cleanliness of the city $(0,30)$ have a significant impact on global tourist satisfaction.

By carrying out the same type of analysis on the data of the II wave, we obtained diverse results. In this case, on the base of the gathered data, it is possible to pinpoint different satisfying, neutral and dissatisfying factors.

In particular, among satisfying factors, we can list again the accommodation, catering/restaurants/etc., the price/quality ratio, hospitable local people and other (not specified by us) activities that are interesting for the tourists interviewed. Differently from the results showed above, between the satisfying factors, there are also amusement, availability of touristic information and the quality of streets and road-signs (table 8), that, in the previous period, was considered a dissatisfying factor.
Table 7. Attributable risk (I wave).

\begin{tabular}{ll}
\hline Item & I wave \\
\hline & RA \\
Easy access through different modes of transportation & 0,20 \\
Quality of streets and road-signs & 0,07 \\
Accommodation & 0,27 \\
Restaurants' quality and diversity & 0,10 \\
Entertainment & 0,05 \\
Price and value & 0,23 \\
On stage information accessibility & 0,11 \\
Public transportation & 0,17 \\
Perceived security & 0,08 \\
Disabled-friendly infrastructures & 0,17 \\
Cleanliness of the city & 0,30 \\
Other (not specified by the questionnaire) activities that & 0,30 \\
are interesting for tourists interviewed & 0,40 \\
Hospitable (local) people. & 0,17 \\
Organization of cultural events & \\
\hline
\end{tabular}

Table 8. Satisfaiers factors (II wave)

\begin{tabular}{|c|c|c|c|c|}
\hline & Accommodation & Restaurants' quality and diversity & Entertainment & Price and value \\
\hline unsatisfied & 5,94 & 2,68 & 5,94 & 5,94 \\
\hline uninteresting & 17,82 & 10,71 & 17,82 & 17,82 \\
\hline \multirow[t]{3}{*}{ satisfied } & 76,24 & 86,61 & 76,24 & 76,24 \\
\hline & 100 & 100 & 100 & 100 \\
\hline & Quality of streets and road-signs & On stage information accessibility & Hospitable (local) people & Other activities \\
\hline unsatisfied & 5,94 & 14,95 & 5,56 & 8,06 \\
\hline uninteresting & 17,82 & 26,17 & 16,67 & 33,87 \\
\hline \multirow[t]{2}{*}{ satisfied } & 76,24 & 58,88 & 77,78 & 58,06 \\
\hline & 100,00 & 100,00 & 100,00 & 100,00 \\
\hline
\end{tabular}

Table 9. Internal consistency (Cronbach $\alpha$ ) Neutral/satisfier factors (II wave)

\begin{tabular}{lll}
\hline & $\begin{array}{l}\text { Easy access through different } \\
\text { modes of transportation }\end{array}$ & $\begin{array}{l}\text { Cultural events' } \\
\text { organization }\end{array}$ \\
\hline unsatisfied & 5,95 & 12,77 \\
uninteresting & 36,90 & 37,23 \\
satisfied & 57,14 & 50,00 \\
& 100 & 100 \\
\hline
\end{tabular}

Also the neutral/satisfying factors are different: in this mixed class, there are now easy access through different modes of transportation and organization of cultural events (table 9).

Finally, like in the first case, all the services delivered by the city of Naples are listed among dissatisfying factors (table 10).

Table 10. Dissatisfiers factors (II wave)

\begin{tabular}{lllll}
\hline & $\begin{array}{l}\text { Public } \\
\text { transportation }\end{array}$ & $\begin{array}{l}\text { Perceived } \\
\text { security }\end{array}$ & $\begin{array}{l}\text { Disabled - } \\
\text { friendly } \\
\text { infrastructures }\end{array}$ & $\begin{array}{l}\text { Cleanliness } \\
\text { of the city }\end{array}$ \\
\hline unsatisfied & 33,33 & 38,83 & 37,50 & 56,19 \\
uninteresting & 23,53 & 23,30 & 43,06 & 24,76 \\
satisfied & 43,14 & 37,86 & 19,44 & 19,05 \\
& 100 & 100 & 100 & 100 \\
\hline
\end{tabular}

In addition to this, in order to appreciate the magnitude of each indicator on the global satisfaction, we calculated the attributable risk (table 11).
Table 11. Internal consistency (Cronbach $\alpha$ )

\begin{tabular}{ll}
\hline Item & I wave \\
\hline & RA \\
Easy access through different modes of transportation & 0,06 \\
Quality of streets and road-signs & 0,13 \\
Accommodation & 0,27 \\
Restaurants' quality and diversity & 0,31 \\
Entertainment & 0,30 \\
Price and value & 0,21 \\
On stage information accessibility & 0,19 \\
Public transportation & 0,20 \\
Perceived security & 0,22 \\
Disabled-friendly infrastructures & 0,08 \\
Cleanliness of the city & 0,11 \\
Other (not specified by the questionnaire) activities that & 0,30 \\
are interesting for tourists interviewed & 0,32 \\
Hospitable (local) people. & 0,23 \\
Organization of cultural events & \\
\hline
\end{tabular}

\section{Conclusions and Hints for the Future}

This study investigated the effects of some destination attributes on the generation of customer satisfaction.

According to a great deal of scientific literature, tourist satisfaction can influence some behaviours such as customer retention as well as word-of-mouth or word-of-mouse processes.

The empirical section of this paper proposed a demand analysis based on data collected via questionnaire in order to 
reveal the global tourist satisfaction, measured by using partial satisfaction indexes. In particular, the study analysed: 1 . services provided by city (i.e. public transportation and perceived security, etc.), 2. services offered by local firms (i.e. hotel, restaurants, night clubs, etc.); and 3. other services, provided by Public Administration and local firms, such as cultural events (Cooper, Fletcher, Gilbert, Wanhill, 1993; Della Corte, 2009). The focus of our investigation was a city in the South of Italy, Naples.

The findings of this research support that Naples has not a clear destination image. Consequently, if we consider this latter assertion, it is possible to state that tourists visiting Naples are not completely satisfied. More precisely, Naples is denoted by a very conflicting image: on one side, it is associated to excellent food tradition and to natural and artistic beauties but, on the other side, it is perceived as a dirty place and characterized by criminality and disorganization. Moreover, the magnitude of Neapolitan cultural, historical and traditional heritage is under-dimensioned in tourists' perceptions.

From this study, it comes out that tourist satisfaction depends on a complex process where the role of each actor is fundamental and it must be in tune with all the other ones.

According to these results, it is clear that the correct individuation of the main factors that can generate customer satisfaction is fundamental to orient future strategic actions. Furthermore, the longitudinal analysis showed that it is more than ever necessary the realization of orchestration strategies, enacted by both local public and private actors to remove negative factors (or to reduce their impact) and to amplify the effects of positive factors influencing tourist satisfaction.

Thus, from a theoretical point of view, the paper presents a focus on customer satisfaction with specific reference to service industries. These are peculiar since the service is evaluated in the same time of its provision, thus making it very difficult and challenging for firms to propose adequate offers to an increasingly needful demand. Both methods and tools are proposed. Besides, these results are very useful for decision makers since they drive the process of managing tourism offer connected with tourist image, in an experience-based view. The limitations regard the fact that the empirical analysis was carried out just in a specific area and should be extended to other destinations for further comparisons.

\section{References}

[1] J. Alegre, J. Garau, "Tourist satisfaction and dissatisfaction," in Annals of Tourism Research, vol. 1, 2010, pp. 52-73.

[2] L. Arussy, "The experience! How to wow your customers and create a passionate workplace," San Francisco: CMP Books, 2002.

[3] M. Augustyn, S. K. Ho, "Service quality and tourism," in Journal of Travel Research vol. 37, 1998, pp. 71-75.

[4] R. P. Bagozzi, "Evaluating structural equation models with unobservable variables and measurement error: a comment," in Journal of Marketing Research, 1981, pp.375-381.
[5] J. E. Bigné, L. Andreu, J. Gnoth, "The theme park experience: An analysis of pleasure, arousal and satisfaction," in Tourism Management, vol. 26, 2005, pp. 833-844.

[6] J. E. Bigne, M. I. Sanchez, J. Sanchez, "Tourism image, evaluation variables and after purchase behaviour: inter-relationship," in Tourism management, vol. 22, 2001, pp. 607-616.

[7] D. J. Flint, C. P. Blocker, P. J. Boutin Jr, "Customer value anticipation, customer satisfaction and loyalty: An empirical examination," in Industrial Marketing Management, vol. 40, 2011, pp. 219-230.

[8] D. Bowen, A. F. Schouten, "Tourist satisfaction and beyond: tourist migrants in Mallorca," in International Journal of Tourism Research, vol. 10, 2008, pp. 141-153.

[9] M. K. Brady, C. J. Robertson, "Searching for a consensus on the antecedent role of service quality and satisfaction: an exploratory cross-national study," in Journal of Business Research, vol. 51, 2001, pp. 53-60.

[10] B. Bramwell, "User satisfaction and product development in urban tourism," in Tourism Management, vol. 19, 1998, pp. $35-47$.

[11] J. Brown, A. J. Broderick, N. Lee, "Word of mouth communication within online communities: Conceptualizing the online social network," in Journal of interactive marketing, vol. 21, 2007, pp. 2-20.

[12] E. R. Cadotte, N. Turgeon, "Key factors in guest satisfaction," in Cornell Hotel and Restaurant Administration Quarterly, vol. 28, 1998, pp. 45-51.

[13] C. F. Chen, D. Tsai, "How destination image and evaluative factors affect behavioral intentions?," in Tourism management, vol. 28, 2007, pp. 1115-1122.

[14] B. Cherry, L. D. Ordóñez, S. W. Gilliland, "Grade expectations: The effects of expectations on fairness and satisfaction perceptions," in Journal of Behavioral Decision Making, vol. 16, 2003, pp. 375-395.

[15] D. Chhabra, R. Healy, E. Sills, "Staged authenticity and heritage tourism," in Annals of tourism research, vol. 30, 2003, pp. 702-719.

[16] A. Coghlan, "Linking natural resource management to tourist satisfaction: a study of Australi"s Great Barrier reef," in Journal of Sustainable Tourism, vol. 20, 2011, pp. 41-58.

[17] C. Cooper, J. Fletcher, D. Gilbert, S. Wanhill, "Tourism principles and practice," London: Addison Wesley Longman, 1993.

[18] P. Corbetta, " Metodologia e tecniche della ricerca sociale," Bologna: Il Mulino, 1999.

[19] J. L. Crompton, "Motivations for Pleasure Vacation," in Annals of Tourism Research, vol. 6, 1979, pp. 408-424.

[20] P. J. Danaher, N. Arweiler, "Customer Satisfaction in the Tourist Industry. A Case Study of Visitors to New Zealand," in Journal of Travel Research, v. 35, 1996, pp. 89-93.

[21] M. J. Daniels, E. B. Drogin Rodgers, B. P. Wiggins, “<<Travel Tales >: an interpretive analysis of constraints and negotiations to pleasure travel as experienced by persons with physical disabilities," in Tourism Management, v. 26, 2005, pp. 919-930. 
[22] G. Dann, G., "Anomie, ego-enhancement and tourism," in Annals of tourism research, vol. 4, 1977, pp. 184-194.

[23] R. T. Rust, R. W. Oliver, "The death of advertising," in Journal of Advertising, v. 23, 1994, pp. 71-77.

[24] I. R. Del Bosque, H. S. Martín, "Tourist satisfaction a cognitive-affective model," in Annals of Tourism Research, v. 35, 2008, pp. 551-573.

[25] V. Della Corte, "Imprese e sistemi turistici: il management. II Edizione,", Milano: Egea, 2013.

[26] V. Della Corte, "Imprese e Sistemi Turistici: il Management," Milano: Egea, 2009.

[27] V. Della Corte, R. Micera, "Il caso della Penisola Sorrentina," in S. Sciarelli, "Il management dei sistemi turistici locali: strategie e strumenti per la governance," Torino: Giappichelli, 2007.

[28] S. Hosany, Y. Ekinci, M. Uysal, "Destination image and destination personality: An application of branding theories to tourism places," in Journal of Business Research, v. 59, 2006, pp. 638-642.

[29] Y. Ekinci, P. Prokopaki, C. Cobanoglu, "Service quality in Cretan accommodations: marketing strategies for the UK holiday market," in International Journal of Hospitality Management, v. 22, 2003, pp. 47-66.

[30] Y. Ekinci, E. Sirakaya-Turk, S. Preciado, "Symbolic consumption of tourism destination brands," in Journal of Business Research, v. 66, 2013, pp. 711-718.

[31] T. Falk, M. Hammerschmidt, J. J. Schepers, “The service quality-satisfaction link revisited: exploring asymmetries and dynamics," in Journal of the Academy of Marketing Science, v. 38, 2010, pp. 288-302.

[32] B. H. Ferns, A. Walls, "Enduring travel involvement, destination brand equity, and travelers' visit intentions: A structural model analysis," in Journal of Destination Marketing \& Management, v. 1, 2012, pp. 27-35.

[33] K. Fields, "Demand for the gastronomy tourism product: motivational factors," in Tourism and gastronomy, 2002, pp. 36-50.

[34] D. J. Flint, C. P. Blocker, P. J. Boutin Jr, P. J., "Customer value anticipation, customer satisfaction and loyalty: An empirical examination", Industrial Marketing Management, v. 40, 2011, pp. 219-230.

[35] J. R. Fonseca, "Customer satisfaction study via a latent segment model," in Journal of Retailing and Consumer Services, v. 16, 2009, pp. 352-359.

[36] C. Fornell, "A national customer satisfaction barometer: the Swedish experience," in Journal of Marketing, v. 56, 1992, pp. 6-21.

[37] C. Fornell, S. Mithas, F. V. Morgeson III, F. V., M. S. Krishnan, "Customer satisfaction and stock prices: high returns, low risk," in Journal of Marketing, v. 70, 2006, pp. 3-14.

[38] B. Frank, T. Enkawa, "Economic influences on perceived value, quality expectations and customer satisfaction," in International Journal of Consumer Studies, v. 33, 2009, pp. 72-82.

[39] G. Giampaglia, "Lo scaling unidimensionale nella ricerca sociale," Napoli: Liguori, 1990.
[40] D. Grewal, M. Levy, V. Kumar, "Customer experience management in retailing: an organizing framework," in Journal of Retailing, v. 85, 2009, pp. 1-14.

[41] U. S. Grissemann, N. E. Stokburger-Sauer, "Customer co-creation of travel services: The role of company support and customer satisfaction with the co-creation performance," in Tourism Management, v. 33, 2012, pp. 1483-1492.

[42] J. Hartley, K. McWilliam, J. Burgess, J. Banks, "The uses of multimedia: Three digital literacy case studies," in Media International Australia, Incorporating Culture \& Policy, n. 128, 2008, pp. 59-72.

[43] R. S. Hartman, "The Hartman Value Profile (HVP): Manual of interpretation, research concepts," Southern Illinois: Muskegon, 1973.

[44] P. Hetzel, "Planète conso: Marketing expérientiel et nouveaux univers de consummation," Paris: Editions d'Organisation, 2002.

[45] B. Higgs, M. J. Polonsky, M. Hollick, "Measuring expectations. Forecast vs. ideal expectations. Does it really matter?," in Journal of Retailing and Consumer Services, v. 12, 2005, pp. 49-64.

[46] S. Hosany, Y. Ekinci, M. Uysal, "Destination image and destination personality: An application of branding theories to tourism places," in Journal of Business Research, v. 59, 2006, pp. 638-642.

[47] J. R. Ritchie, S. Hudson, "Understanding and meeting the challenges of consumer/tourist experience research," in International Journal of Tourism Research, v. 11, 2009, pp. 111-126.

[48] T. K. Hui, D. Wan, A. Ho, "Tourists' satisfaction, recommendation and revisiting Singapore," in Tourism management, v. 28, 2007, pp. 965-975.

[49] J. K. S. Jacobsen, A. M. Munar, "Tourist information search and destination choice in a digital age," in Tourism Management Perspectives, v. 1, 2012, pp. 39-47.

[50] O. H. Jenkins, "Understanding and measuring tourist destination images," in International Journal of Tourism Research, v. 1, 1999, pp. 1-15.

[51] A. M. Kaplan, D. Schoder, M. Haenlein, "Factors influencing the adoption of mass customization: The impact of base category consumption frequency and need satisfaction," in Journal of product innovation management, v. 24, 2007, pp. 101-116.

[52] J. H. Kim, J. S. Chen, "The effects of situational and personal characteristics on consumer complaint behavior in restaurant services," in Journal of Travel \& Tourism Marketing, v. 27, 2010, pp. 96-112.

[53] P. Kotler, D. H. Haider, I. Rein, "Marketing Places: Attracting Investment, Industry, and Tourism to Cities, States and Nation," New York: The Free Press, 1993.

[54] M. Kozak, M. Rimmington, "Benchmarking: destination attractiveness and small hospitality business performance," in International Journal of Contemporary Hospitality Management, v. 10, 1998, pp. 184-188.

[55] M. Kozak, M. Rimmington. "Measuring tourist destination competitiveness: conceptual considerations and empirical findings", in International Journal of Hospitality Management, 1999, v.18, pp. 273-283. 
[56] M. Kozak, "Repeaters' behaviour at two distinct destination," in Annals of Tourism Research, v. 28, 2001, pp. 784-807.

[57] S. Kruger, C. Rootenberg, C., S. Ellis, "Examining the influence of the wine festival experience on tourists' quality of life," in Social indicators research, v. 111, 2013, pp. 435-452.

[58] V. Kumar, V., J. A. Petersen, "Using a customer-level marketing strategy to enhance firm performance: a review of theoretical and empirical evidence," in Journal of the Academy of Marketing Science, v. 33, 2005, pp. 504-519.

[59] W. Reinartz, J. S. Thomas, V. Kumar, "Balancing acquisition and retention resources to maximize customer profitability," in Journal of Marketing, v. 69, 2005, pp. 63-79.

[60] Y. F. Kuo, C. M. Wu, W. J. Deng, "The relationships among service quality, perceived value, customer satisfaction, and post-purchase intention in mobile value-added services," in Computers in human behavior, v. 25, 2009, pp. 887-896.

[61] S. Y. Lam, V. Shankar, M. K. Erramilli, B. Murthy, "Customer value, satisfaction, loyalty, and switching costs: an illustration from a business-to-business service context," in Journal of the Academy of Marketing Science, v. 32, 2004, pp. 293-311.

[62] D. LaSalle, T. Britton, "Priceless: Turning ordinary products into extraordinary experiences," Harvard: Harvard Business Press, 2003.

[63] R. S. Lazarus, "Emotion and adaptation," Oxford: Oxford University Press, 1991.

[64] G. Lee, J. T. O'Leary, G. S. Hong, "Visiting propensity predicted by destination image: German long-haul pleasure travelers to the US," in International Journal of Hospitality \& Tourism Administration, v. 3, 2002, pp. 63-92.

[65] S. Lee, S. Jeon, D. Kim, "The impact of tour quality and tourist satisfaction on tourist loyalty: The case of Chinese tourists in Korea," in Tourism Management, v. 32, 2011, pp. 1115-1124.

[66] B. Loken, B., "Consumer psychology: categorization, inferences, affect, and persuasion," in Annual Review of Psychology, v. 57, 2006, pp. 453-485.

[67] K. A. Machleit, S. P. Mantel, "Emotional response and shopping satisfaction: moderating effects of shopper attributions," in Journal of Business Research, v. 54, 2001, pp. 97-106.

[68] B. Merrilees, D. Miller, C. Herington, "Antecedents of residents' city brand attitudes," in Journal of Business Research, v. 62,2009 , pp. 362-367.

[69] J. Mikulić, D. Prebežac, Evaluating hotel animation programs at Mediterranean sun-and-sea resorts: An impact-asymmetry analysis," in Tourism Management, v. 32, 2011, pp. 688-696.

[70] F. V. Morgeson III, S. Mithas, T. L. Keiningham, L. Aksoy, “An investigation of the cross-national determinants of customer satisfaction," in Journal of the Academy of Marketing Science, v. 39, 2011, pp.198-215.

[71] R. Nash, M. Thyne, S. Davies, "An investigation into customer satisfaction levels in the budget accommodation sector in Scotland: a case study of backpacker tourists and the Scottish Youth Hostels Association," in Tourism Management, v. 27, 2006, pp. 525-532.

[72] K. Nield, M. Kozak, G. LeGrys, "The role of food service in tourist satisfaction," in International Journal of Hospitality Management, v. 19, 2000, pp. 375-384.
[73] L. Nilsson, M. D. Johnson, A. Gustafsson, "The impact of quality practices on customer satisfaction and business results: product versus service organizations," in Journal of Quality Management, v. 6, 2001, pp. 5-27.

[74] J. C. Nunnally, "Psychometric Theory", New York: McGraw-Hill, 1978.

[75] R. L. Oliver, R. S. Winer, "A framework for the formation and structure of consumer expectations: review and propositions," in Journal of Economic Psychology, v. 8, 1987, pp. 469-499.

[76] R. L. Oliver, R. R. Burke, "Expectation Processes in Satisfaction Formation A Field Study," in Journal of Service Research, v. 1, 1999, pp. 196-214.

[77] R. L. Oliver, J. E. Swan, "Consumer perceptions of interpersonal equity and satisfaction in transactions: A field survey approach," in Journal of Marketing, v. 53, 1989, pp. 21-35.

[78] M. Oppermann, "Tourism destination loyalty", Journal of Travel Research, v. 39, 2000, pp. 78-84.

[79] E. Ortega, B. Rodriguez, "Information at tourism destinations. Importance and cross-cultural differences between international and domestic tourists," in Journal of Business Research, v. 60, 2007, pp.146-152.

[80] P. L. Ostrowski, T. V. O'Brien, G. L. Gordon, "Service quality and customer loyalty in the commercial airline industry," in Journal of Travel Research, v. 32, 1993, pp. 16-24.

[81] B. J. Pine, J. H. Gilmore, “The experience economy,” Harvard, Harvard Business Press, 2011.

[82] A. Postma, K. A. Jenkins, "Improving the Tourist's Experience: Quality Management applied to Tourist Destinations," in E.P. Murphy Eds., New York: Quality Management in Urban Tourism, Wiley, 1997.

[83] J. Y. Qi, J. P. Zhou, W. J. Chen, Q. X. Qu, "Are customer satisfaction and customer loyalty drivers of customer lifetime value in mobile data services: a comparative cross-country study," in Information Technology and Management, v. 13, 2012, pp. 281-296.

[84] I. R. Del Bosque, H. S. Martín, "Tourist satisfaction a cognitive-affective model," in Annals of Tourism Research, v. 35, 2008, pp. 551-573.

[85] E. L. Dunn Ross, S. E. Iso-Ahola, "Sightseeing tourists' motivation and satisfaction," in Annals of tourism research, v. 18, 1991, pp. 226-237.

[86] R. T. Rust, A. J. Zahorik, T. L. Keiningham, "Return on quality (ROQ): Making service quality financially accountable," in Journal of Marketing , v. 59, 1995, p. 58-70.

[87] M. Konecnik Ruzzier, L. De Chernatony, "Developing and applying a place brand identity model: the case of Slovenia," in Journal of Business Research, v. 66, 2013, pp. 45-52.

[88] B. Trauer, B., C. Ryan, "Destination image, romance and place experience-an application of intimacy theory in tourism," in Tourism Management, v. 26, 2005, pp. 481-491.

[89] F. Selnes, "Antecedents and consequences of trust and satisfaction in buyer-seller relationships," in European Journal of Marketing, v. 32, 1998, pp. 305-322.

[90] C. Shaw, J. Ivens, "Building Great Customer Experiences," London: Prentice-Hall, 2005. 
[91] C Shaw, J. Ivens, "Building Great Customer Experiences", Basingstoke: PalgraveMacmillan, 2002.

[92] M. Sherif, C. I. Hovland, "Social judgment: Assimilation and contrast effects in communication and attitude change", Oxford: Yale Univer. Press, 1961.

[93] S. L. Smith, "The tourism product," in Annals of Tourism Research, v. 21, 1998, pp. 582-595.

[94] S. Smith, J. Wheeler, "Managing the customer experience: Turning customers into advocates," Edinburgh Gate: Pearson Education, 2002.

[95] M R. Solomon, "Consumer behavior," Singapore: Prentice-Hall, 1992.

[96] H. Song, R. van der Veen, G. Li, J. L. Chen, “The Hong Kong Tourist Satisfaction Index," in Annals of Tourism Research, v. 39, 2012, pp. 459-479.

[97] R. A. Spreng, C. Dröge, "The impact on satisfaction of managing attribute expectations: should performance claims be understated or overstated?," in Journal of Retailing and Consumer Services, v. 8, 2001, pp. 261-274.

[98] R. M. Stock, "How does product program innovativeness affect customer satisfaction? A comparison of goods and services," in Journal of the Academy of Marketing Science, v. 39, 2011, pp. 813-827.

[99] A. D. Tasci, Y. Boylu, "Cultural comparison of tourists' safety perception in relation to trip satisfaction," in International Journal of Tourism Research, v. 12, 2010, pp. 179-192.

[100] K. Thompson, P. Schofield, "An investigation of the relationship between public transport performance and destination satisfaction", Journal of Transport Geography, v. 15, 2007, pp. 136-144.

[101] J. Tribe, J., T. Snaith, "From SERVQUAL to HOLSAT: holiday satisfaction in Varadero, Cuba," in Tourism Management, v. 19, 1998, pp. 25-34.

[102] M. D. Uncles, R. East, W. Lomax, "Good customers: The value of customers by mode of acquisition," in Australasian Marketing Journal, v. 21, 2013, pp. 119-125.

[103] A. Usakli, S. Baloglu, "Brand personality of tourist destinations: An application of self-congruity theory," in Tourism Management, v. 32, 2011, pp. 114-127.

[104] M. Uysal, C. Jurowski, "Testing the push and pull factors," in Annals of Tourism Research, v. 21, 1994, pp. 844-846.

[105] W. Van Dolen, K. De Ruyter, J. Lemmink, (2004), “An empirical assessment of the influence of customer emotions and contact employee performance on encounter and relationship satisfaction," in Journal of Business Research, v. 57, 2004, pp. 437-444.

[106] S. Veasna, W. Wu, C. Huang, "The impact of destination source credibility on destination satisfaction: The mediating effects of destination attachment and destination image," in Tourism Management, v. 36, 2013, pp. 511-526.

[107]F. Vetter, "Critères de definition du tourisme des grandes métropoles," in F. Vetter (Ed.), Big City Tourism, Berlin: Dietrich Reimer Verlag, 1985.

[108] R. Voase, "Recognition, reputation and response: Some critical thoughts on destinations and brand," in Journal of Destination Marketing \& Management, v. 1, 2012, pp. 78-83.

[109] G. Walsh, V. W. Mitchell, P. R. Jackson, S. E. Beatty, "Examining the antecedents and consequences of corporate reputation: a customer perspective," in British Journal of Management, v. 20, 2009, pp. 187-203.

[110] Y. K. P. Wan, S. H. J. Chan, "Factors that Affect the Levels of Tourists' Satisfaction and Loyalty towards Food Festivals: a Case Study of Macau," in International Journal of Tourism Research, v. 15, 2013, pp. 226-240.

[111] Y. Wang, H. P. Lo, Y. Yang, "An integrated framework for service quality, customer value, satisfaction: evidence from China's telecommunication industry," in Information Systems Frontiers, v. 6, 2004, pp. 325-340.

[112] R. A. Westbrook, R. L. Oliver, "The dimensionality of consumption emotion patterns and consumer satisfaction," in Journal of consumer research, v. 18, 1991, pp. 84-91.

[113] W. Xia, Z. Jie, G. Chaolin, Z. Feng, "Examining Antecedents and Consequences of Tourist Satisfaction: A Structural Modeling Approach," in Tsinghua Science and Technology, v. 14, 2009, pp. 397-406.

[114]Z. Yang, R. T. Peterson, "Customer perceived value, satisfaction, and loyalty: the role of switching costs," in Psychology \& Marketing, v. 21, 2004, pp. 799-822.

[115] S. Yastrow, "Brand Harmony: Achieving Dynamic Results by Orchestrating Your Customer's Total Experience," New York: SelectBooks, Inc., 2003.

[116] Y. Yoon, M. Uysal, "An examination of the effects of motivation and satisfaction on destination loyalty: a structural model," in Tourism management, v. 26, 2005, pp. 45-56.

[117] Y. T. Yu, A. Dean, "The contribution of emotional satisfaction to consumer loyalty," in International journal of service industry Management, v. 12, 2001, pp. 234-250.

[118] L. Yu, L., M. Goulden, “A comparative analysis of international tourists' satisfaction in Mongolia," in Tourism Management, vol. 27, 2006, pp. 1331-1342.

[119] L. Zhao, Y. Lu, L. Zhang, P. Y. Chau, "Assessing the effects of service quality and justice on customer satisfaction and the continuance intention of mobile value-added services: An empirical test of a multidimensional model," in Decision Support Systems, v. 52, pp. 645-656. 